\title{
En 55 år gammel mann med residiverende hjerneinfarkt
}

\author{
En 55 år gammel mann ble innlagt to ganger med hjerneinfarkt som \\ antatt komplikasjon til cervikal arteriedisseksjon. Uventede funn ved \\ en planlagt kontroll ga behov for å tenke nytt. Etter en mer omfattende \\ utredning tror vi nå at pasienten har hatt to uavhengige, uvanlige \\ årsaker til hjerneinfarkt.
}

Se kommentar side 1092 og kunnskapsprøve på www.tidsskriftet.no/quiz

\author{
Lasse Pihlstrøm \\ lasse.pihlstrom@oslo-universitetssykehus.no \\ Kristin Å. Alfstad \\ Volker Solyga \\ Nevrologisk avdeling \\ Geir André Ringstad \\ Radiologisk avdeling \\ Emilia Kerty \\ Nevrologisk avdeling
}

Oslo universitetssykehus, Rikshospitalet

Pasienten, en 55 àr gammel mann, ble innlagt i lokalsykehus etter 11 dagers sykehistorie preget av flere akutte episoder med varierende nevrologiske utfall. Han var ikkerøyker og hadde ingen familieanamnese for cerebrovaskulær sykdom. Tidligere i livet hadde han hatt en uklart beskrevet episode med forbigående synstap og en annen med akutt vertigo og oppkast, oppfattet som perifert betinget. Vesentlige symptomer og funn nå var diplopi, høyresidig ptose, vertigo, parestesier $i$ venstre kroppshalvdel og lett nedsatt tempo i venstre sides ekstremiteter. CT caput og dopplerundersøkelse av halskar var beskrevet som negative, men det ble påvist et pseudoaneurisme på høyre a. carotis interna ved CT-angiografi (fig 1), og han ble henvist vår avdeling for videre utredning.

Ved cerebral MR ble det påvist to små, subakutte infarkter i høyre mesencephalon. Pseudoaneurismet ble vurdert som sannsynlig sekvele etter arteriell disseksjon. MR-angiografi viste det som ble oppfattet som en føtal variant, med a. cerebri posterior avgående fra carotis interna. En slik karanatomi kunne forklare embolisering fra carotis til mesencephalon. Det ble utført transtorakal ekkokardiografi, med normale funn. Koagulasjonsutredning ble ikke gjort. Anamnestisk kom det frem at symptomene oppsto etter manipulasjonsbehandling hos kiropraktor.
Hos vår pasient var det altså ikke funn som tydet på aterosklerose eller hjertesykdom. Ved fravær av disse de hyppigste årsakene til hjerneinfarkt var det naturlig å legge vekt på funnet av pseudoaneurisme og betrakte disseksjon som sannsynlig etiologi. Cervikal arteriedisseksjon gir i første rekke symptomer i form av smerter og lokale virkninger av hematomet i karveggen. Et flertall av pasientene har ensidige nakke-, hals- eller hodesmerter. Ved carotisdisseksjon beskriver mange smerter bak øret eller utstråling ved kjevevinkelen. Slike plager fikk vi ikke frem hos vår pasient. Sympatiske nervefibre følger a. carotis interna, og affeksjon av disse gir ensidig Horners syndrom hos en stor andel av pasientene (1). Denne mekanismen representerer den mest sannsynlige årsaken til høyresidig ptose hos vår pasient. Mindre vanlige lokale symptomer ved carotisdisseksjon er pulsatil tinnitus eller hjernenerveutfall.

Slike lokale symptomer er direkte virkninger av hematomet som dannes i karveggen ved disseksjon. Dette vil i noen tilfeller ekspandere innover og gi stenosering av karlumen, med nedsatt blodstrøm og cerebral iskemi. Hvis det derimot ekspanderer utover, dannes en aneurismeliknende dilatasjon av karet, svarende til det radiologiske funnet som ble gjort hos vår pasient. I tilknytning til slike karforandringer kan det dannes trombemateriale, som ved embolisering kan gi hjerneinfarkt eller transitorisk iskemisk anfall (TIA). Forsinkelsen i tid mellom de lokale symptomene og iskemiske komplikasjoner kan være fra minutter til uker (2). Ved carotisdisseksjon vil man forvente symptomer fra områder som forsynes fra fremre kretsløp, typisk halvsidige motoriske eller sensoriske utfall, afasi eller amaurosis fugax. Det så imidlertid ut som om vår pasient hadde en anatomisk variant der også a. cerebri posterior forsynes fra fremre kretsløp, noe som minner oss om de betydelige individuelle variasjonene $\mathrm{i}$ hjernens blodforsyning.
Det er anslått en årlig insidens av cervikal arteriedisseksjon på 2,6 per 100000 innbyggere. Trolig er det reelle tallet høyere, siden lette eller asymptomatiske tilfeller ofte ikke blir oppdaget (2). Tilstanden diagnostiseres ved ikke-invasive undersøkelser som ultralyddoppler, CT-angiografi eller MR/MRangiografi. Det foreligger ikke studier som gir grunnlag for entydige råd om behandling. Vanlige behandlingsstrategier er platehemming (acetylsalisylsyre, klopidogrel) eller antikoagulasjon (warfarin/lavmolekylært heparin). Hvor lenge behandlingen bør vare, og hvorvidt man trenger profylakse hvis man ikke har hatt iskemiske komplikasjoner, er kontroversielle spørsmål. I spesielle tilfeller kan carotisendarterektomi eller endovaskulær intervensjon bli aktuelt.

Pasienten ble utskrevet med acetylsalisylsyre og avtale om kontroll. Omtrent et år

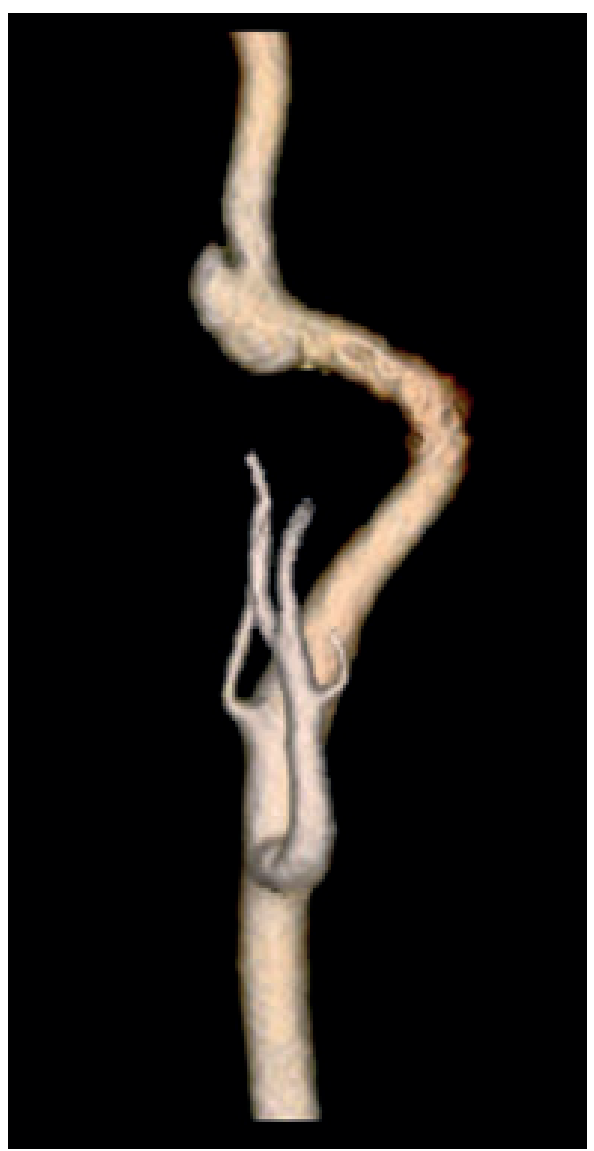

Figur 1 CT-angiografi ltredimensjonal rekonstruk sjon) viser funn forenlig med pseudoaneurisme på høyre a. carotis interna halvveis mellom bifurkasjonen og skallebasis, passende med status etter gjennomgått disseksjon 


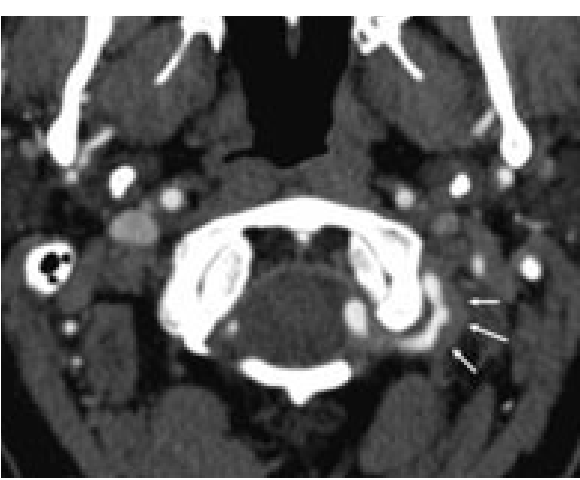

Figur 2 Aksial CT-angiografi viser uregelmessig kontrastførende lumen og patologisk veggfortykkelse av venstre vertebralisarterie (piler) i nivå C1/C2

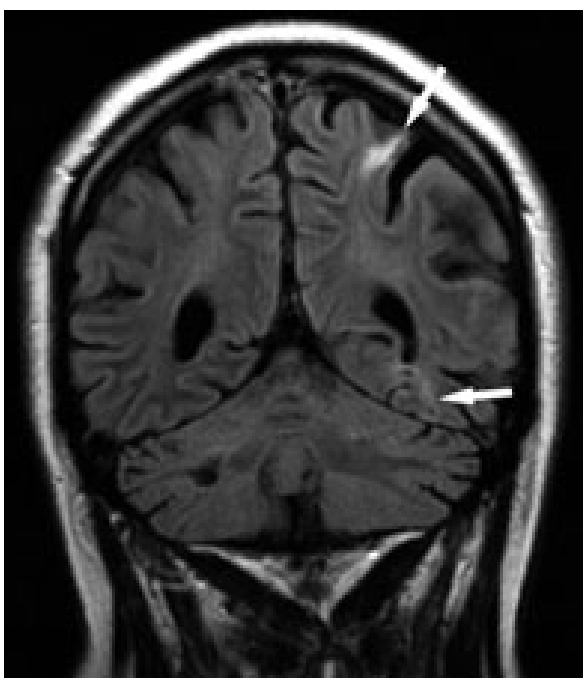

Figur 3 MR med FLAIR-sekvens (fluid attenuated inversion recoveryl viser flere nye små iskemiske lesjoner (piler) i venstre hemisfære

senere ble han innlagt på nytt - med akutt dysartri og uvelhet som debuterte under kiropraktorbehandling. Bildediagnostikk viste ferske infarkter i begge cerebellarhemisfærer og veggforandringer $i$ venstre a. vertebralis, forenlig med ny disseksjon (fig 2). Kardiolog fant ikke indikasjon for transøsofageal ekkokardiografi, fordi det forelå kjent embolikilde. Det ble målt normale verdier for homocystein og protein $C$ og S, og faktor V-/Leiden-mutasjonen ble utelukket. Man la om fra acetylsalisylsyre til klopidogrel og planla kontroll etter et halvt år.

Det kliniske bildet ved cervikal arteriedisseksjon reflekterer den affiserte arteriens omkringliggende strukturer og forsyningsområde. Symptombildet ved vertebralisdisseksjon vil i tråd med dette skille seg fra det man ser ved carotisdisseksjon. Smertene lokaliseres gjerne til bakhodet. Hematomet kan gi trykk mot cervikale nerverøtter og rotsymptomer. Intrakranial vertebralisdisseksjon kan i sjeldne tilfeller kompliseres med ruptur av pseudoaneurisme og subaraknoidalblødning. Symptomer på cerebral iskemi vil typisk kunne knyttes til områder forsynt av bakre kretsløp, eksempelvis dysartri, vertigo, diplopi og ataksi.

Det er anslått en årlig langtidsrisiko for residiv av cervikal arteriedisseksjon på omkring $1 \%$ når sykdommen ikke er familiært betinget (3). Risikofaktorene er ikke de samme som for aterosklerotisk karsykdom. Det er rapportert sammenheng med blant annet hyperhomocysteinemi, infeksjon, migrene med aura og hormonell antikonsepsjon. I tillegg er det kjent at bindevevssykdommer som Marfans syndrom, Ehlers-Danlos syndrom og fibromuskulær dysplasi disponerer for disseksjon (4).

Mange pasienter forteller om traumer mot nakke eller hals før symptomdebut. Disse kan imidlertid være av såpass triviell karakter at man antar at det samtidig må foreligge predisponerende faktorer. I flere studier er det funnet en overhyppighet av manipulasjonsterapi hos kiropraktor eller manuell terapeut forut for disseksjonen, men spørsmålet om hvorvidt det eksisterer en årsakssammenheng er kontroversielt (5). Sannsynligvis foreligger en risiko ved slik behandling. Den er riktignok svært liten, tatt i betraktning det store antallet som hvert år får kiropraktorbehandling.

I dette tilfellet finner vi det mest sannsynlig at en spontan disseksjon er blitt tolket av vår pasient som nakkesmerter relatert til bevegelsesapparatet. Selve nakkemanipulasjonen kan så ha vært utløsende årsak til at en trombe har løsnet fra karveggen og gitt akutt hjerneinfarkt.

Ved kontroll et halvt år senere hadde det ikke vært akutte episoder med subjektive symptomer, og pasienten anga å være $i$ langsom bedring. Imidlertid gjorde vi enkelte overraskende funn. Ved undersøkelse fant vi betydelig nedsatt tempo i høyre hånd. Dette var ikke beskrevet tidligere. MR cerebrum avdekket flere nye små iskemiske lesjoner $i$ venstre hemisfære (fig 3). Denne gangen var det ingen forandringer $i$ aktuelle arterier som kunne forklare infarktene.

Hvorfor fikk pasienten stadig gjentatte små hjerneinfarkter? I mangel av holdepunkter for aterosklerose eller disseksjon tenkte vi på muligheten for oversett hjertesykdom, trombosetendens, vaskulitt eller andre sjeldne vaskulopatier.

Utredningen ble nå supplert med spinalpunksjon, EEG-undersøkelse, omfattende koagulasjonsutredning og transøsofageal ekkokardiografi. I forløpet av dette hadde pasienten ytterligere en episode med akutt svimmelhet, og det ble påvist en liten aktuell lesjon i cerebellum. Spinalvæsken viste lett forhøyet proteinverdi, men normalt celletall. Det var lette, uspesifikke forandringer i EEG. Blodprøver viste forhøyede nivåer av lupusantikoagulant (ratio 2,04), antikardiolipin$\lg G$ (> $410 \mathrm{GPL}-\mathrm{U} / \mathrm{ml}$ ) og anti- $\beta 2$-glykoprotein 1-lgG $(96 \mathrm{U} / \mathrm{ml})$. Ved transøsofageal ekko fant man rundaktige tumorer på mitral-og aortaklaffen, forenlig med ikke-bakteriell endokarditt.

Blodbildet tydet på diagnosen antifosfolipidsyndrom. Klaffeforandringer er også assosiert med denne tilstanden. Antifosfolipidsyndrom er en autoimmun tilstand som kjennetegnes ved trombose eller obstetrisk sykdom hos pasienter med antifosfolipidantistoffer. Ifølge internasjonal konsensus må minst ett klinisk kriterium og ett laboratoriekriterium være oppfylt for at man kan stille diagnosen (ramme 1) (6).

Hvis tilstanden opptrer uten assosiasjon til annen sykdom, brukes betegnelsen primært antifosfolipidsyndrom. Sekundært antifosfolipidsyndrom ses særlig ved systemisk lupus erythematosus, men kan også skyldes annen autoimmun sykdom, malignitet eller medikamenter. Antifosfolipidantistoffer er påvist hos opp mot $10 \%$ av friske kontrollpersoner, men opptrer da oftest forbigående. De forekommer hyppigere hos eldre og kronisk syke, og finnes hos $30-50 \%$ av dem med systemisk lupus erythematosus (7). Det er først ved allerede gjennomgått trombose at risikoen for nye tromboser er betydelig økt. Dette gjenspeiles ved at også et klinisk kriterium må være oppfylt for at diagnosen antifosfolipidsyndrom kan stilles. Trombose på venesiden er hyppigst, mens TIA eller hjerneinfarkt er første kliniske manifestasjon hos til sammen $20 \%$ (7).

Pasienten får nå antikoagulasjonsbehandling med warfarin. Etter drøfting med koagulasjonsekspert ble INR-målsettingen satt til 2,5, og han fortsatte samtidig med acetylsalisylsyre $75 \mathrm{mg}$ daglig. Ved grundig anamnese kom det i retrospekt frem at pasienten gjennom hele forløpet hadde hatt relativt hyppige episoder med kortvarig, monokulært synstap, både på høyre og venstre side. Dette hadde han vært så vant med at han ikke hadde funnet det naturlig à ta det opp med lege. Etter oppstart med warfarin har han ikke lenger slike hyppige amaurosis fugax-episoder.

I samråd med revmatolog er det også startet behandling mot antifosfolipidsyndrom med hydroksyklorokin $200 \mathrm{mg} \times 2$. Nivået av antifosfolipidantistoffer har vært forhøyet også ved senere kontroller.

Pasienten følges nå hos revmatolog med tanke på sekundært antifosfolipidsyndrom som ledd i systemisk lupus erythematosus. Det har vært små, uspesifikke avvik i antinukleære antistoffer og komplementanalyser, men ingen kliniske tegn eller urinfunn som støtter denne diagnosen. Det har heller ikke vært funn som tyder på generalisert vaskulittilstand. Når det gjelder muligheten for primær vaskulitt i sentralnervesystemet, har pasienten ikke hodepine og normalt celletall i spinalvæsken. Dette støtter ikke en slik diagnose, selv om det ikke er tilstrekkelig for å 


\section{Ramme 1}

\section{Reviderte Sapporo-kriterier, noe forenklet, etter Miyakis og medarbeidere (6)}

Antifosfolipidsyndrom er til stede hvis minst ett klinisk kriterium og ett laboratoriekriterium er oppfylt. Avstanden i tid mellom klinisk episode og laboratoriefunn skal være mellom 12 uker og 5 år.

Kliniske kriterier

- Klinisk episode med venøs eller arteriell trombose

- Obstetrisk sykdom

Uforklart fosterdød etter 10 . svangerskapsuke, eller

prematur fødsel før uke 34 grunnet eklampsi eller placentainsuffisiens, eller

minst tre påfølgende uforklarte spontanaborter før uke 10

Laboratoriekriterier

- Lupusantikoagulant til stede ved to eller flere målinger med minst 12 ukers avstand $i$ tid

- Antikardiolipin-IgG eller -lgM til stede (medium eller høyt titer) ved to eller flere målinger (ELISA) med minst 12 ukers avstand $i$ tid

- Anti- $\beta 2$-glykoprotein 1-IgG eller -IgM til stede (titer $>99$-prosentilen) ved to eller flere målinger (ELISA) med minst 12 ukers avstand $\mathrm{i}$ tid

utelukke den helt. I tillegg er det utført CTangiografi på tre ulike tidspunkter både av pre- og intracerebrale kar uten tegn på vaskulitt. Gullstandarden for påvisning av vaskulitt i sentralnervesystemet er konvensjonell angiografi, men CT-angiografi kan gi mistanke hvis en slik tilstand foreligger.

\section{Diskusjon}

En rekke kliniske trekk er assosiert med antifosfolipidsyndrom uten å inngå i de diagnostiske kriteriene. Dette gjelder klaffesykdom, trombocytopeni, livedo reticularis og nyreaffeksjon. Det diskuteres også en mulig sammenheng med flere ikke-trombotiske, nevrologiske tilstander, slik som kognitiv dysfunksjon, migrene, multippel sklerose, transvers myelitt og epilepsi, men dette er ikke sikkert etablert (6). Katastrofalt antifosfolipidsyndrom er en sjelden, akutt, systemisk variant av sykdommen, med multiorganaffeksjon og høy mortalitet.

Om lag en tredel av pasientene med primært antifosfolipidsyndrom har klaffeforandringer, enten som generell fortykkelse eller knuter (8). Funn av små, sterile vegetasjoner, som hyppigst affiserer mitral- og aortaklaffen, er kjent som Libman-Sacks' endokarditt. Det er holdepunkter for å anta at antifosfolipidantistoffer spiller en etiologisk rolle i utviklingen av klaffeforandringer, og klaffesykdom antas å representere en tilleggsrisiko for cerebral emboli hos pasienter med antifosfolipidsyndrom.

Det finnes ikke studier som har vist nytte av antitrombotisk primærprofylakse hos asymptomatiske pasienter med antifosfolipidantistoffer. I slike situasjoner bør man imidlertid vurdere risikoen individuelt og i størst mulig grad eliminere øvrige faktorer som kan gi økt trombosetendens. Den sentrale behandlingen ved antifosfolipidsyndrom er sekundær tromboseprofylakse. Generelt anbefales warfarin (9), selv om enkelte data taler for at acetylsalisylsyre kan være like effektivt etter første gangs hjerneinfarkt (7). Optimal varighet og intensitet av antikoagulasjonsbehandling er ikke godt dokumentert. Som i dette tilfellet må derfor slike beslutninger fattes ut fra klinisk skjønn og individuelle vurderinger. For gravide gjelder egne anbefalinger. Immunmodulerende medikamenter antas å få en viktigere rolle i behandlingen av antifosfolipidsyndrom i fremtiden. Hydroksyklorokin har både antiinflammatoriske og antitrombotiske egenskaper og er aktuelt som tilleggsbehandling til antikoagulasjon hos enkelte (9) Statiner og rituximab er eksempler på andre preparater som diskuteres.

Denne sykehistorien illustrerer godt utfordringene ved utredning etter hjerneinfarkt. Vår pasient har fătt påvist to relativt sjeldne årsaker til residiverende cerebrovaskulæ sykdom. I en slik situasjon er det naturlig å spørre seg om disse virkelig er uavhengige, eller om det snarere dreier seg om en felles bakenforliggende tilstand. Noe bastant svar på dette kan vi ikke gi, men vi har ikke funnet holdepunkter i litteraturen for en kjent sammenheng mellom cervikal arteriedisseksjon og primært antifosfolipidsyndrom.

Vi kom først på sporet av ytterligere en viktig årsak til hjerneinfarkt da det ble tydelig at vår hypotese ikke kunne forklare alle pasientens symptomer og funn. Det er derfor et godt prinsipp å ha en kritisk innstilling og et bredest mulig vurderingsgrunnlag når man stiller sannsynlig etiologisk diagnose etter hjerneinfarkt. Kasuistikken illustrerer også betydningen av å være sensitiv overfor uventede funn og ha lav terskel for å revurdere diagnosen. Også pasienter som kommer til rutinekontroll, kan by på overraskelser. Dersom kartet ikke passer med terrenget, må kanskje utredningen gjentas og suppleres med andre eller mer sensitive undersøkelser.

Pasienten har gitt samtykke til at artikkelen blir publisert.

\section{Lasse Pihlstrøm (f. 1980)}

har vært assistentlege ved Nevrologisk avdeling, Oslo universitetssykehus, Rikshospitalet, og er nå doktorgradsstipendiat samme sted. Ingen oppgitte interessekonflikter.

\section{Kristin Å. Alfstad (f. 1966)}

er fra 2011 overlege ved Avdeling for kompleks epilepsi - SSE, Oslo universitetssykehus. Hun har nylig avsluttet spesialistutdanningen i nevrologi.

Ingen oppgitte interessekonflikter.

\section{Volker Solyga (f. 1973)}

er spesialist i nevrologi, utdannet ved bl.a. Nevrologisk avdeling, Oslo universitetssykehus, Rikshospitalet. Han er overlege ved Nevrologisk avdeling, Sykehuset Østfold, Fredrikstad Ingen oppgitte interessekonflikter.

\section{Geir André Ringstad (f. 1972)}

er overlege i nevroradiologi ved Avdeling for radiologi og nukleærmedisin Oslo universitetssykehus, Rikshospitalet. Jobbet tidligere ved radiologisk avdeling ved Sykehuset Østfold, Fredrikstad.

Ingen oppgitte interessekonflikter.

\section{Emilia Kerty (f. 1948)}

er spesialist i øyesykdommer og nevrologi. Hun er seksjonsoverlege ved Nevrologisk avdeling. Oslo universitetssykehus, Rikshospitalet, og professor ved Universitetet i Oslo. Ingen oppgitte interessekonflikter.

\section{Litteratur}

1. Kerty E. The ophthalmology of internal carotid artery dissection. Acta Ophthalmol Scand 1999; 77 $418-21$

2. Debette S, Leys D. Cervical-artery dissections: predisposing factors, diagnosis, and outcome. Lancet Neurol 2009; 8: 668-78.

3. Brandt T, Orberk E, Grond-Ginbach C. Klinik und Therapie der Dissektionen hirnversorgender Arterien. Nervenarzt 2006; 77 (S01): 17-30.

4. Rubinstein SM, Peerdeman SM, van Tulder MW et al. A systematic review of the risk factors for cervical artery dissection. Stroke 2005; 36 : $1575-80$

5. Miley ML, Wellik KE, Wingerchuk DM et al. Does cervical manipulative therapy cause vertebral artery dissection and stroke? Neurologist 2008; 4. $66-73$

6. Miyakis S, Lockshin MD, Atsumi T et al. International consensus statement on an update of the classification criteria for definite antiphospholipid syndrome (APS). J Thromb Haemost 2006; 4 295-306.

7. Lim W, Crowther MA, Eikelboom JW. Managemen of antiphospholipid antibody syndrome: a systematic review. JAMA 2006; 295: 1050-7.

8. Hojnik M, George J, Ziporen L et al. Heart valve involvement (Libman-Sacks endocarditis) in the antiphospholipid syndrome. Circulation 1996; 93 : 1579-87.

9. Erkan D, Lockshin MD. New approaches for managing antiphospholipid syndrome. Nat Clin Pract Rheumatol 2009; 5: 160-70 